\title{
IMPROVEMENT OF CUSTOMS AND TAX ADMINISTRATION ICT SYSTEM PERFORMANCE
}

\author{
Māra Pētersone ${ }^{1}$, Kārlis Ketners² \\ ${ }^{1}$ Riga Technical University, Latvia \\ ${ }^{2} \mathrm{BA}$ School of Business and Finance, Latvia \\ Mara.Petersone@rtu.lv
}

\begin{abstract}
Nowadays ICT has a significant role in public administration by creating opportunities to automate a lot of manual operations. ICT plays an important role both in improving customer service in public administrations as well as internal and inter-institutional co-operation processes in public administrations that promote access to services and service quality, facilitate administrative processes for citizens and businesses and contribute to the accessibility of information. Public authority daily faces a major challenge - on the one hand to reduce labour costs and on the other hand to introduce innovations. In the implementation of both these objectives public administrations deal with a serious problem - to operate in a connected environment by involving stakeholders and at the same time to solve problems by using new working methods, tools and management models. One of the strategic objectives of tax and customs administrations is to increase resource use efficiency and effectiveness; therefore, they continuously search solutions to simplify administrative procedures, to improve and develop the quality of services provided and the business environment in general, and how to automate internal work processes and significantly reduce manual workload. This study aims to examine the structure affecting the efficiency indicators, to point out the factors which have the biggest impact on increasing effectiveness of institutions.
\end{abstract}

Key words: Tax and customs administrations, information and telecommunication systems, productivity, efficiency, manual work.

\section{Introduction}

One of the strategic objectives of tax and customs administrations is to increase resource use efficiency and effectiveness; therefore, they continuously search solutions to simplify administrative procedures, to improve and develop the quality of services provided and the business environment in general, and how to automate internal work processes and significantly reduce manual workload.

In the OECD and non-OECD countries one commonly used performance indicator for tax administrations is their total revenue body expenditure as a percentage of GDP and the cost of collection ratio, which compares the aggregate tax administration cost per 100 units of net tax revenue collected (OECD, 2014). When calculating the cost of one euro collected, in most cases three categories of costs - administrative expenses, remuneration costs, and Information and communications technology (ICT) costs are taken into account, as they play a key role in smooth functioning of the public administration.

With the development of modern technologies and new working methods, the existing work processes are revised from the perspective of innovations, replacing the historic and traditional working methods with new and advanced ones, thus making work processes more efficient. It is generally believed that such replacement is important from a resource use perspective, allowing more efficient use of the means of production. While preserving the old system and adding new elements and tasks, it will still be necessary to maintain both the old resources for performing standard functions and continually adding new resources to ensure that new activities are implemented. In this formation, a lack of resources and the need for new employees will always be felt.

The authors agree to Pang's et al. opinion that 'the majority of studies in the information systems (IS) discipline have focused on discovering IT business value in for-profit organizations, the performance effects of IT in the public sector have not been extensively studied neither in the IS nor the public administration literature' (Pang et al., 2014).

The authors put forward the argument that the increase of the role of information and communication technology and decrease of manual work in public administration ensures that efficiency indicators will increase. This study aims to examine the structure affecting the performance indicators, to point out the factors which have the biggest impact on increasing the effectiveness of institutions. ICT efficiency and effectiveness having impact on the performance indicator are the target of current research. To achieve the aim, the following objectives are pursued:

- to determine the types of expenditures affecting the SRS performance indicator;

- to analyze the existing ICT expenditure, recovery costs and structure of labour force in the Latvian State Revenue Service (SRS);

- to propose improvements of the mechanism for calculating resource savings by replacing manual workflows with ICTs.

The information compiled by SRS statistic, scientific publications of foreign and local researchers, and other materials have been used for the purpose 
of the study. The research is mainly based on the monographic descriptive method as well as the methods of analysis and synthesis.

\section{Problem Statement}

Nowadays ICT has a significant role in public administration by creating opportunities to automate a lot of manual operations. ICT plays an important role both in improving customer service in public administrations, as well as internal and inter-institutional co-operation processes in public administrations that promote access to services and service quality, facilitate administrative processes for citizens and businesses and contribute to the accessibility of information. Public authority daily faces a major challenge - on the one hand to reduce labour costs and on the other hand to introduce innovations. In the implementation of both these objectives public administrations deal with a serious problem - to operate in a connected environment by involving stakeholders and at the same time to solve problems by using new working methods, tools and management models.

'The scale of society's evolving challenges gradually surpasses the capacity of the public sector to address them. Coping with these challenges requires budget-short governments to look for innovative ways to transform and improve their operations and service provisioning models while in many cases transformation starts from the inside-out (based on policy goals) and focuses on reorganization through ICTs' (Klievink et al., 2016).

Scientists studying the role of ICT in public authority stress its positive effects on a range of the organization's internal performance determinants efficiency, effectiveness, accountability, management quality, simplified government procedures and external factors such as improved interaction with citizens, connectivity, openness (Sun, 2011; Nugroho, 2014; Ibrahim et al., 2015; Ochara-Muganda \& Van Belle, 2010; Bonina \& Cordella, 2009).

The authors completely agree with Dečman and Klun that tax administration gains from ICT use, however, tax administration systems are among the most complex ones (Dečman \& Klun, 2009). Janssen and Estevez point to the fact that in the foreseeable future public authorities will have to shift from the 'traditional approaches - like electronic government (e-Government) and transformational government (t-Government) to 'lean government' (1-Government) - a new wave which is appearing as a response to and aims at reducing the complexity of the public sector by simplifying and streamlining organizational structures and processes, at the same time at stimulating innovation by mobilizing stakeholders' (Janssen \& Estevez, 2013).
Tax and customs administrations, and any other public administrations whose operations to a great extent are based on intellectual and manual work, possess the ability to absorb a virtually unlimited number of employees and the only limiting element is the allocated funding. The human factor determines that resources allocated to work are never sufficient. The existence of such a factor determines the fact that the management of the institution has to perform regular assessment of the workload and optimal resource allocation for human resources and ICT.

The leader in the use of information technology among the Baltic States is Estonia because, as shown by the Global Information Technology Report data of the World Economic Forum (WEF) 2015, Latvia ranks 33 in the field of ICT in the world, whereas Lithuania has maintained the 31 st place and Estonia ranks 22. It has developed historically, because since 2000 the institutions in Estonia have focused on their core functions and outsourcing IT services, while the Latvian and Lithuanian authorities have mainly relied on their own internal resources to provide ICT services. WEF points out that Estonia's powerful performance and constant growth of Latvian ICT which is approaching the Lithuanian position allow the Baltic countries 'slowly but surely close the gap with the Nordic countries, which is a considerable achievement for the three former Soviet republics' (Dutta, Geiger, \& Lanvin, 2013).

Administrative costs increase due to manual document circulation between the public administrations and the Latvian SRS and also between the public administrations and taxpayers. Despite the government's decisions on the circulation of documents between the public administrations with a secure electronic signature, not all Latvian public administrations implement the decisions adopted by the government. For example, insolvency applications still cannot be submitted electronically. In addition, in Latvia the proportion of physical persons who choose to settle their obligations to the state in person is still large. In 2015, in Latvia $41 \%$ of physical persons submitted their annual income declarations in paper form in person, while in Estonia, 95\% of physical persons submitted their annual income declarations electronically. Already in 2013, 96\% of Lithuanian residents submitted their annual income declarations electronically. In Estonia, electronic submission of annual income declaration of physical persons started in 2000, in Lithuania in 2004, but in Latvia only in 2008. In all three countries, the situation is very similar with the corporate income tax and VAT annual income declarations, which are submitted electronically in $98 \%$ of cases. 


\section{Data analysis}

Authors agree with Coste \& Tudor (2013) 'Service performance in public sector entities should provide high quality information, the way funds should be allocated should be transparent, efficient resource use without raising questions about resource use and eliminate uncertainty in the quality of services'. In this context, exactly the replacement of manual work with ICT should lead to the improvement of the whole organization's performance. Considering that the performance indicator in most cases takes into account the three types of expenditures - administrative, remuneration and Information and Communications Technology (ICT) expenditures, the research will examine the remuneration and ICT expenditures because the proportion of administrative expenditures is relatively small compared to the other two types of expenditures.

Taking into consideration the increasing amount of data to be accumulated and processed by the tax and customs administrations, the role of ICT in tax administration processes is growing. In Latvia, 2011 was a milestone in the communication between the SRS and taxpayers, when a mandatory requirement was introduced for the majority of taxpayers (legal entities and separate groups of physical persons) to submit tax reports only in an electronic form using the Electronic Declaration System (EDS) (see Figure 1).

Figure 1 illustrates that taxpayers - legal entities and separate groups of persons who were identified as obliged to submit documents to the SRS in electronic form - have started to submit the most significant and most extensive part of the reports which were meant to be entered by SRS officers manually in the SRS IT systems before the SRS electronisation in 2011. Figure 1 demonstrates that the number of documents transmitted electronically grew rapidly in 2010. This is due to the fact that some groups of SRS clients, who regularly submit their reports and declarations with intent to prepare themselves to this requirement, started to do it in the electronic form already in 2010. 2010 was a transition period of the SRS electronicization. Figure 1 demonstrates that within the period of eight years the proportion of documents submitted to the SRS on paper and in electronic format has changed totally opposite.

In search for solutions to reduce manual work, Latvian SRS has gained significant resource savings by introducing submission of the most important taxpayers' reports - value added tax return, annual corporate income tax declaration, report on state social insurance mandatory contributions (SSC) from the income for work of the employees, company's annual report and the personal income tax (PIT) as well as business risk-related state duty in the reference month - in the electronic declaration system (EDS).

In addition to the improvement of the EDS, the Latvian SRS also works on the development of its other information and telecommunication systems on the basis of changes in the national and EU legislation and by optimizing internal processes when manual work is replaced with automatic control. The electronic customs data processing system (EMDAS) and its subsystems provide the opportunity to electronically submit such customs declarations and documents as entry summary declaration, import declaration, export declaration, export declaration with the exit summary data, re-export notification, exit summary declaration, transit declaration, TIR declaration, transit and TIR declaration with the summary declaration data, manifests/temporary storage module - (air transport) manifest, temporary storage declaration, information related to stock control of goods in temporary storage. According to the requirements of the EU legislation, economic operators and other persons involved in customs formalities use unique economic operators registration and identification number - EORI number when dealing with customs authorities throughout the

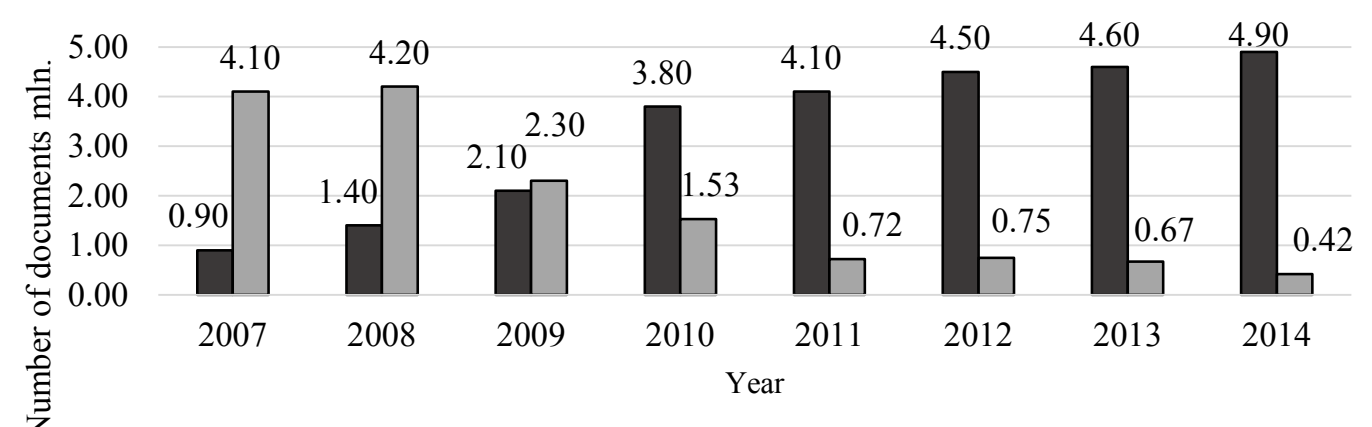

$\square$ In electronic form submitted number of documents

$\square$ In paper form submitted number of documents

Figure 1. The proportion of documents sent in electronic and paper form in the SRS

(The State Audit Office of the Republic of Latvia, 2015). 


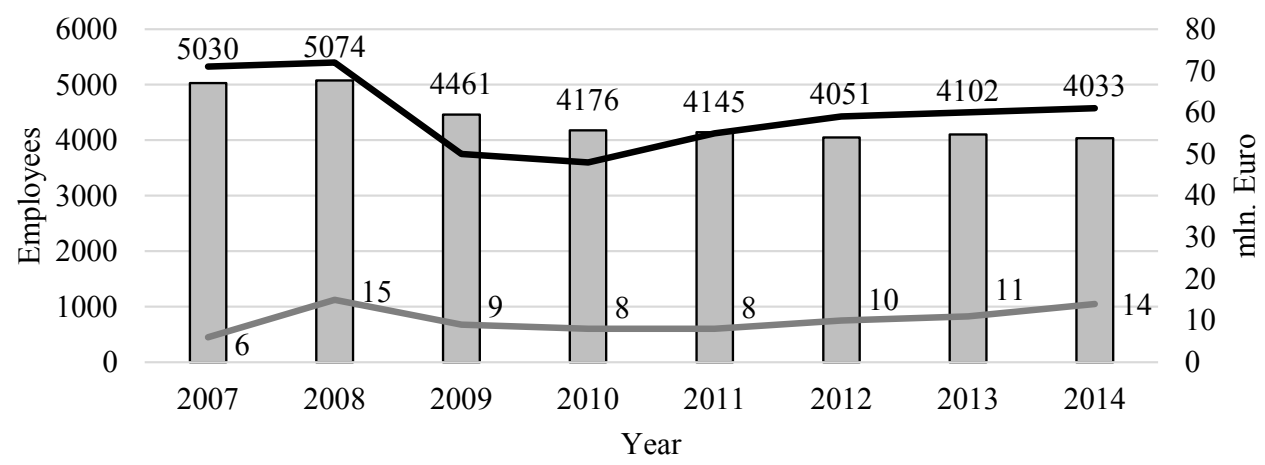

$\square$ The number of employees in the SRS

The expenditure of the SRS on ICT services and software (mln. Euro)

The expenditure of the SRS on remuneration (mln. Euro)

Figure 2. The expenditure of the Latvian SRS on ICT, remuneration and the number of employees.

EU. Like all EU states, Latvia uses Excise Movement and Control System (EMCS).

When comparing the SRS expenses for remuneration and ICT services, it is observed that ICT services costs increase in proportion to remuneration expenses. ICT and remuneration expenses showed a rapid reduction in 2009 , which is attributed to the consolidation measures during the crisis, whereas starting from 2012 expenses for ICT and remuneration have been gradually increasing (see Figure 2).

Figure 1 demonstrates that electronic document submission has reduced manual work in the Latvian SRS that was used for transferring the data submitted by the taxpayers to the ICT systems; however (see Figure 2), electronic document submission actually has not influenced the number of employees. The total increase of the Latvian SRS remuneration may be due to the overall increase in funding for public administration after the economic crisis of 2009. Expenditures for ICT and software in 2014 were almost equal to the 2008 level (pre-crisis), unlike the remuneration part. Due to the accounting peculiarities in the Latvian SRS, it is not possible to obtain reliable and valid data on the Latvian SRS savings after introducing electronic document submission process because the Latvian SRS does not gather such data; though according to expert estimates, more than ten workloads have been saved.

Although the number of employees since 2010 has been slowly increasing, development of the EDS functions not only has led to a cascading effect of reductions in manual work in the Latvian SRS, but has also influenced issues such as the quality of the Latvian SRS data information systems and decrease in the number of errors in the submitted documents. The quality of the Latvian SRS data in the information systems has grown, the number of errors in the submitted documents has decreased resulting in the decrease in the amount of work needed for the examination of the quality of declarations. Starting to use the EDS for mutual communication with taxpayers has resulted in savings on office supplies and postage expenses.

\section{Results and Discussion}

National governments, following the New Public Management (NPM) guidelines, introduced private principles and instruments in the public field to improve the efficiency, effectiveness and financial stability of state enterprise (Calogero, 2010). This means that in order to achieve the strategic objectives of public authorities, it is necessary to assess two vitally important factors - human resources and ICT and their interaction required for reaching strategic goals and performance indicators. Gershon believes that 'Government policy-making emphasis worldwide is moving increasingly to how IT can be used to achieve efficiency savings' (Gershon, 2004).

However, in order to calculate what effect can be achieved by modernizing the work process, it is crucial to have accurate understanding of the existing work processes and the time consumed when the already existing work methods are applied.

Work estimating methods are work process research and design techniques aimed at defining the workload. The Latvian SRS has chosen to introduce the analytical work estimating method (Кибанов, 1998), which is based on process management (Pētersone \& Ketners, 2016b).

In order to objectively evaluate the resource savings due to the replacement of manually performed work processes with ICT, it would be necessary to perform analysis of all core activities. International experience shows that the evaluation procedure (identifying work processes, recording times necessary for each task, abandoning unnecessary activities) performance 
helps tax administrations in work optimization, more efficient operation and resource use. For example, the Estonian tax administration devoted two years for the identification of each process, measurements, etc., including setting the necessary amount of human resources for each process, and it allowed the Estonian Tax and Customs Board to reduce resource consumption in 2013 by $2.3 \%$ and in 2014 by another $3.9 \%$. Due to the development of Estonia's electronic environment, already for a long period of time the Estonian Tax and Customs Board has worked on partial or even full automatization of functions or performing them without unnecessary bureaucracy. For example, one of the most important tax administration processes for which the SRS annually allocates significant resources is the refunding of overpaid personal income tax on the basis of annual income declarations submitted by the residents. Annual income declaration submission in both countries is possible by electronic means, but it is still manually inspected in Latvia. In Estonia, this resource-intensive process has been fully automated for several years due to the electronic data flow from employers, banks and other public authorities. Thus, submission of annual income declarations does not need accompanying supporting documents. In Estonia, the amount of expenditure for which residents can receive refunding is also smaller due to different national legislation, for example, the exemptions are not applied to medical and dental charges.

The SRS has ensured the quality of performance measurements by linking it to the process control systems creating a SRS results matrix, where each indicator is attributed to one of the processes and process steps (Pētersone, Krastiņš, \& Ketners, 2015). However, together with the idea about the process and function identification, it would be necessary to begin developing work time tracking, in order to obtain comprehensive information on the number of resource-intensive and time-consuming tasks and processes thus providing information and support for determining the necessary resources. To implement work time tracking, it would be necessary to:

- assess the tasks, processes, performance indicators and human resource allocation for each process according to the competence of the institution;

- provide time tracking for each process, determining the time spent and performance outcomes;

- estimate costs (both direct and indirect) for each process (Pētersone \& Ketners, 2016a);

- assess the available data on the time consumed and cost of the processes by determining the optimal human resource consumption and reducing this consumption or replacing it by process automation.
'An investment in IT that only achieves an improvement of PA internal efficiency through increased productivity and a reduction in production costs will be halfway through the achievement of its objective, as that internal efficiency does not help to increase the taxpayer's satisfaction with the public service received' (Bigliardi \& Dormio, 2009).

Before initiating the process of replacing manual work with ICT solutions, the Latvian SRS has to evaluate such strategic questions as:

- whether all the functions performed by the SRS correspond to the aims of the Latvian SRS;

- the enforcement of legislation, which increases the work process costs;

- the probability of duplication of delegated tasks and processes with other public administrations;

- the increase of the number of employees involved in support processes;

- the absence of internal work estimating standards.

However, the most significant factor determining the efficiency of tax and customs administration is the human factor. Fakhrutdinova et al. stress that 'among a set of problems of increasing the efficiency of public civil service, it is necessary to underline the following: replenishment of administrative staff with highly professional and competent experts and an increase of a professional level of the public civil servants in the process of performance of their functional duties (Fakhrutdinova et al., 2015)' Chlivickas points out: 'the main focus should be laid on improvement of state structures efficiency and increment of professionalism and accountability of human resources in state institutions' (Chlivickas, 2015).

\section{Conclusions}

1. Taking into consideration the increasing amount of data to be accumulated and processed by the tax and customs administrations, the role of ICT in tax administration processes is growing. In the communication between the SRS and taxpayers a mandatory requirement has been introduced for the majority of taxpayers and the clients of the customs administration to submit tax reports and customs documents only in an electronic form using the Electronic Declaration System (EDS).

2. Due to the accounting peculiarities in the Latvian SRS, it is not possible to obtain reliable data on the Latvian SRS savings after introducing electronic document submission process because the Latvian SRS does not gather such data. Electronic document submission has reduced manual work in the SRS; however, it actually has not influenced the 
number of employees. Any mechanical reduction of personnel without deep investigation of the processes may create a threat when the amount of work in different workplaces may sharply rise or drop.

3. When comparing the Latvian SRS expenses for remuneration and ICT services, it is observed that ICT services costs increase in proportion to remuneration expenses. Submission of electronic documents has reduced the SRS's manual work; however, the electronic submission of documents did not actually affect the number of employees. The SRS, whose work is based mostly on intellectual and manual work, has the capacity to absorb practically unlimited numbers of people and the only one restrictive element is just the funding which has steadily increased since the crisis in 2009, but has not achieved the level of 2008.
4. The Latvian SRS has chosen to introduce the analytical work estimating method, which is based on process management. However, in order to calculate what effect can be achieved by replacing manual work processes with ICT solutions, it is crucial to have accurate understanding of the existing work processes and appropriate accounting and estimating.

5. Before initiating the process of replacing manual work with ICT solutions, the SRS has to evaluate such strategic questions as whether all the functions performed by the SRS correspond to the aims of the Latvian SRS, the enforcement of legislation, which increases the work process costs, the probability of duplication of delegated tasks and processes with other public administrations, the increase of the number of employees involved in support processes and the absence of internal work estimating standards.

\section{References}

1. Bigliardi, B., \& Dormio, A.I. (2009). New management models of public administration: The Italian experience of e-Government. In 9th European Conference on e-Government, ECEG 2009 (pp. 137 - 148). London; United Kingdom.

2. Bonina, C.M., \& Cordella, A. (2009). Public sector reforms and the notion of 'public value': Implications for e-government deployment. In 15th Americas Conference on Information Systems, AMCIS 2009. Vol. 1, 2009 (pp. 469 - 476). San Francisco, CA; United States.

3. Calogero, M. (2010). The Introduction of New Public Management Principles in the Italian Public Sector. Transylvanian Review of Administrative Sciences, 30E, 30 - 54.

4. Chlivickas, E. (2014). International cooperation and innovations for developing human resources system. Social and Behavioural Sciences, 110, 276 - 283, DOI: 10.1016/j.sbspro.2013.12.871.

5. Dečman, M., \& Klun, M. (2015). Efficiency and usability of information systems: E-Recovery system in Slovenia. Proceedings of the European Conference on e-Government, ECEG, Vol. 2015-January (pp. $79-86)$.

6. Dutta, S., Geiger, T., \& Lanvin, B. (2015). The Global Information Technology Report 2015. ICTs for Inclusive Growth, Insight Report, ISBN: 978-92-95044-48-7.

7. Fakhrutdinova, E., Yurieva, O., Burganova, L., \& Yurieva, O. (2015). Role of Competence-Based Approach in an Increase of Efficiency of Public Administration. Procedia Economics and Finance 23 (1064 - 1067). Prague; Czech Republic. DOI: 10.1016/S2212-5671(15)00511-0.

8. Gershon, P. (2004). Releasing Resources to the Front Line. Independent Review of Public Sector Efficiency. London; HM Treasury, ISBN-1-84532-032-8.

9. Ibrahim, M., Al-Nasrawi, S., El-Zaart, A., \& Adams, C. (2015). Challenges facing e-government and smart sustainable city: An Arab region perspective. In the European Conference on e-Government, ECEG, Vol. 2015-January, 2015, (pp. 396 - 402).

10. Janssen, M., \& Estevez, E. (2013). Lean government and platform-based governance-Doing more with less. Government Information Quarterly, Vol. 30, Suppl. 1, January 2013, S1 - S8, DOI: http://dx.doi. org/10.1016/j.giq.2012.11.003.

11. Klievink, B., Bharosa, N., \& Tan, Y.-H. (2016). The collaborative realization of public values and business goals: Governance and infrastructure of public-private information platforms. Government Information Quarterly, Vol. 33, Issue 1, 67 - 79, DOI: http://dx.doi.org/10.1016/j.giq.2015.12.002.

12. Nugroho, R. (2014). Electronic government procurement adoption in developing economies: How corruption influences system's adoption. In the European Conference on e-Government, ECEG, Vol. 2014-January, 2014, (pp. 344 - 351).

13. Ochara-Muganda, N., \& Van Belle, J.-P. (2010). The link between the conceptualization of egovernment and its perceived impacts: An exploratory empirical study in Kenya. In 10th European Conference on e-Government, ECEG 2010, (pp. 308 - 319). Limerick; Ireland. 
14. OECD. (2014). Government at a Glance Latin America and the Caribbean 2014: Towards Innovative Public Financial Management, 21 Aug 2014, DOI: 10.1787/9789264209480-en.

15. Pang, M.-S., Tafti, A., \& Krishnan, M.S. (2014). Information technology and administrative efficiency in U.S. state governments: A stochastic frontier approach. MIS Quarterly: Management Information Systems, Vol. 38, Issue 4, $1079-1101$.

16. Pētersone, M., \& Ketners, K. (2016a). Development of revenue authority organization principles which are based on process management. In Economic Science for Rural Development. Latvia; Jelgava (pp. 343 - 351). ISBN 978-9984-48-255-5.

17. Pētersone, M., \& Ketners, K. (2016b). Performance improvements of tax and customs authorities. Case study: Latvia. In 9th International Scientific Conference 'Business and Management - 2016', Lithuania (pp. 1 - 9). Lithuania; Vilnius. DOI: 10.3846/bm.2016.01.

18. Pētersone, M., Krastiņš, A., \& Ketners, K. (2015). Development of System of State Revenue Service Performance Indicators. In Economic Science for Rural Development No.37 (pp. 190 - 200). Latvia; Jelgava.

19. Sun, P. (2011). Analysis on application of information technology in public administrative management. In 2nd International Conference on Artificial Intelligence, Management Science and Electronic Commerce, AIMSEC 2011 (pp. 6542 - 6544).

20. The State Audit Office of the Republic of Latvia (2015). Does the internal reorganization of the State Revenue Service has been effectively carried out?. Retrieved October 22, 2015, from: http://www.lrvk.gov. lv/uploads/reviziju-zinojumi/2014/2.4.1-38_2014/zinojums-publiskosanai22.10.2015.pdf.

21. Кибанов, А.Я. (1998). Управление персоналом: Энциклопедический словарь. (Personnel management: Encyclopedic Dictionary). Москва, ИНФРА-М, ISBN 5-86225-904-X. (in Russian).

22. Coste, A.-I., \& Tudor, A.T. (2013). Service Performance - Between Measurement and Information in the Public Sector. Procedia - Social and Behavioral Sciences, Vol. 92, 215 - 219, DOI: https://doi. org/10.1016/j.sbspro.2013.08.662. 